\title{
$\mathrm{M} \mid \mathrm{R}] \mathrm{S}$

A Publication of the Materials Research Society

Volume 24, Number 7 ISSN: 0883-7694 CODEN: MRSBEA

\section{CORROSION SCIENCE}

12 Corrosion Science

R.C. Newman and K. Sieradzki, Guest Editors

16 Atomic-Scale Processes in Cu Corrosion and Corrosion Inhibition

O.M. Magnussen and R.J. Behm

24 Alloy Corrosion

R.C. Newman, S.G. Corcoran,

J. Erlebacher, M.J. Aziz, and

K. Sieradzki

29 In Situ X-Ray-Diffraction Studies of Passive Oxide Films

M.P. Ryan, M.F. Toney, A.J. Davenport, and L.J. Oblonsky

36 Environment-Assisted Intergranular Cracking J.R. Scully

43 Surface Modification by Ordered Monolayers: New Ways of Protecting Materials Against Corrosion M. Rohwerder and M. Stratmann

\section{MRS NEWS}

48 Robert P. Frankenthal Named Editor-in-Chief of Journal of Materials Research

48 Arun Seraphin Appointed MRS/OSA Congressional Fellow for 1999-2000

50 MRS Spring 1999 Meeting Features Soft, Magnetic, and Display Materials, Among Other Interdisciplinary Research Topics

\section{ABSTRACTS}

66 Abstracts for August 1999 Journal of Materials Research

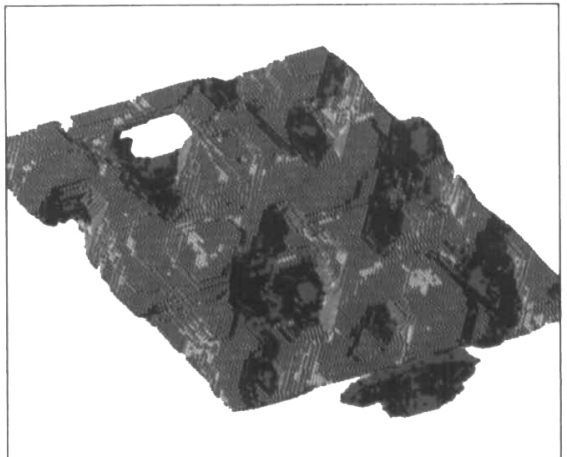

ON THE COVER: Illustrated is the onset of porosity formation in a Kinetic Monte Carlo simulation of selective dissolution of silver (de-alloying) from a $\mathrm{Ag}_{0.9} \mathrm{Au}_{0.1}$ alloy. The skin of the 100 atom $\times 100$ atom section is drawn as if there is a light source off to the side (thus the shaded [dark] areas and seeming transparency). One sees several general features that are characteristics of pore growth in real systems, including (1) creation of a fully three-dimensional porous network, (2) surface enrichment of the more noble metal (gold), and (3) the creation of nanofacets. Simulation results by J. Erlebacher and M.J. Aziz; for more on this subject see the article "Alloy Corrosion" on p. 24.

\section{DEPARTMENTS}
3 Research/Researchers
8 Washington News
9 Public Affairs Forum
11 Resources
42 Advertisers in This Issue
74 Calendar
78 Classified
80 Posterminaries 


\section{About the Materials Research Sociely}

The Materials Research Society (MRS), a not-forprofit scientific association founded in 1973, promotes interdisciplinary goal-oriented basic research on materials of technological importance. Membership in the Society includes over 12,000 scientists, engineers, and research managers from industrial, government, and university research laboratories in the United States and nearly 68 countries.

The Society's interdisciplinary approach differs from that of single-discipline professional societies because it promotes information exchange across the many technical fields touching materials development. MRS sponsors two major international annual meetings encompassing approximately 70 topical symposia, and also sponsors numerous single-topic scientific meetings. The Society recognizes professional and technical excellence and fosters technical interaction in local geographic regions through Sections and University Chapters.

MRS participates in the international arena of materials research through the International Union of Materials Research Societies (IUMRS). MRS is a member of the Federation of Materials Societies and is an affiliate of the American Institute of Physics.

MRS publishes symposium proceedings, MRS

Bulletin, Journal of Materials Research, and other publications related to current research activities.

MRS Bulletin (ISSN: 0883-7694) is published 12 times a year by the Materials Research Society, 506 Keystone Drive, Warrendale, PA 15086-7573. Periodical postage paid at Warrendale, $\mathrm{PA}$ and at additional mailing offices. POSTMASTER: Send address changes to MRS Bulletin in care of the Materials Research Society, at the address listed; phone 724 7793003: fax 724779-8313. Printed in the U.S.A.

Additional copies of articles in MRS Bulletin may be made at $\$ 2.50$ per article. This fee can be paid to the Materials Research Society through the Copyright Clearance Center, Inc., 27 Congress Street, Salem, MA 01970

Membership in MRS is $\$ 80$ annually for regular members, $\$ 25$ for students. Dues include an allocation of $\$ 29$ (\$17 for students) to a subscription to MRS Bulletin. Individual member subscriptions are for personal use only. Non-member subscription rates are $\$ 155$ for one calendar year (12 issues) within the U.S.A. and $\$ 215$ elsewhere. Single copies may be purchased for $\$ 16$ each. Send subscription orders to Subscription Department, Materials Research Society, 506 Keystone Drive, Warrendale, PA 15086-7573. Requests from subscribers for missing journal issues will be honored without charge only if received within six months of the issue's actual date of publication; otherwise, the issue may be purchased at the single-copy price.

MRS Bulletin is included in Current Contents $₫ / E n-$ gineering, Computing, and Technology: Current Contents/Physical, Chemical, and Earth Sciences, the SciSearch ${ }^{\star}$ online database, Research Alert, Science Citation Index $x^{\infty}$ and the Materials Science Citation Index" $x^{n}$. Back volumes of MRS Bulletin are available in $16 \mathrm{~mm}$ microfilm, $35 \mathrm{~mm}$ microfilm, or $105 \mathrm{~mm}$ microfiche through University Microfilms Inc., 300 North Zeeb Road, Ann Arbor, Michigan 48106.

Materials Research Society 506 Keystone Orive

Warrendale, PA 15086-7573 USA

Tel. 724-779-3003; Fax 724-779-8313 http://www.mrs.org/

Editorial Office • 506 Keystone Drive • Warrendale, PA 15086-7573 USA

Tel. 724-779-3004 ext. 522; tax 724-779-8313; http://www.mrs.org/

Editor

E.L. Fleischer

Managing Editor

J. Meiksin

Technical Editor

A. Bertram Wilson

Art Director

E. Stiller

Design/Production

Editorial Assistants

L. Willson and M. Wilmoth
T. Aiello and S. Franklin
Advertising

M.E. Kaufold and D.L. Watterson

Circulation

S. Forrest

Guest Editors

R.C. Newman and K. Sieradzki

Special Contributors

P. Berardelli, A. King,

G.R. Rao, and L. Snyder

Special Consultant

T. Besmann
Associate Editor-Europe

I.W. Boyd, University College London Dept. of Electronic and

Electrical Engineering

Torrington Place

London WCI E7 JE, U.K

Tel. 44-171-380-7300 or 7302

Book Review Board

M.L. Green (Chair), R.W. Cahn,

E.J. Kramer, and J.M. Phillips

MRS Office of Public Affairs

601 13th Street, NW, Suite 1000 South

Washington, DC 20005-3807

Tel. 202-661-2285, Fax 202-661-2299

EDITORIAL BOARD

\section{A.L. Greer, Chair}

Cambridge University

Cambridge, UK

V.S. Arunachalam

Carnegie Mellon University

Pittsburgh, PA

E. Arat

Max-Planck-Institute

Für Metallforschung and

University of Stuttgart

Stuttgart, Germany

R.W. Cahn

Cambridge University

Cambridge, UK

\section{VOLUME ORGANIZERS}

1998

0 . Auciello

Argonne National Laboratory

Argonne, IL

R.J. Composto

University of Pennsylvania

Philadelphia, PA

P.M. Fauchet

University of Rochester

Rochester, NY

VISITING SCIENTISTS

V.S. Arunachalam (1998)

Carnegie Mellon University

Pittsburgh, PA

Cambridge University

Cambridge, UK
S.T. Picraux

Sandia National Laboratories

Albuquerque, NM

Y. Shiohara

ISTEC

Tokyo, Japan

C.C. Tsai

Applied Komatsu Technology

Santa Clara, CA

J.H. Westbrook

Brookline Technologies

Ballston Spa, NY
2000

D.C. Martin

University of Michigan

Ann Arbor, MI

G.M. Pharr

University of Tennessee

Knoxville, TN

A. Polman

FOM Institute

Amsterdam, The Netherlands

\begin{tabular}{lll}
\hline & 1999 MRS EXECUTIVE COMMITTEE \\
\hline President & Treasurer & Councillors \\
R. Gibala & M.J. Mayo & M.J. Aziz \\
University of Michigan & Pennsylvania State University & Harvard University \\
Vice President and President-Elect & Treasurer (Interim) & A. King \\
H.A. Atwater & A. Hurd & State University of New York \\
California Institute of Technology & Sandia National Laboratories & at Stony Brook \\
Secretary & Immediate Past President & Executive Director \\
C.C. Tsai & R.J. Nemanich & Materials Research Society \\
Applied Komatsu Technology & North Carolina State University & John B. Ballance
\end{tabular}

INTERMATIONAL UNION OF MATERIALS RESEARCH SOCIETIES

President $\quad$ First Vice President
H-D.Li
Tsinghua University E.A.Glasow
Beijing, China
IUMRS ADHERING BODIES
Australian Materials Research Society (A-MRS)
J.S. Williams, Australian National University
Chinese Materials Research Society (C-MRS)
H-D. Li, Tsinghua University
European Materials Research Society (E-MRS
I.W. Boyd, University College
Materials Research Society (MRS)
R. Gibala, University of Michigan

\section{Second Vice President}

J.S. Williams

Australian National University

Canberra, Australia

Secretary
L-C Lee
Industrial Technology
Research Institute
Hsinchu, Taiwan

Treasurer

R-I. Yamamoto

University of Tokyo

Tokyo, Japan
Immediate Past President R.C. Ewing

University of Michigan

Ann Arbor, MI, USA
J.S. Williams, Australian National University

Chinese Materials Research Society (C-MRS) H-D. Li, Tsinghua University

I.W. Boyd, University College

R. Gibala, University of Michigan
Materials Research Society of Argentina (MRS-Argentina) J. Feugeas, Universidad Nacional de Rosario

Materials Research Society of India (MRS-I)

R. Chidambaram, Atomic Energy Commission

Materials Research Society of Japan (MRS-J)

T. Kaijyama, Kyushu University

Materials Research Society of Korea (MRS-Korea)

S-J. Park, Seoul National University
Materials Research Society of Russia (MRS-Russia) I.V. Gorynin, Prometey Institute

Materials Research Society of Taiwan (MRS-T)

L.J. Chen, National Tsing Hua University

Mexican Materials Research Society (Mexican-MRS)

L.M. Gomez, Instituto de Fisica UNAM 